\title{
Impact of International Service-Learning on Students' Global Citizenship and Intercultural Effectiveness Development
}

\section{Stephen C. F. Chan}

The Hong Kong Polytechnic University, Hong Kong

Grace Ngai

The Hong Kong Polytechnic University, Hong Kong

Jessie Ho-Yin Yau

The Hong Kong Polytechnic University, Hong Kong

\section{Kam Por Kwan}

The Hong Kong Polytechnic University, Hong Kong

\section{Recommended Citation}




\section{Impact of International Service- Learning on Students' Global Citizenship and Intercultural Effectiveness Development}

\author{
Stephen C. F. Chan, Grace Ngai, \\ Jessie Ho-Yin Yau, and Kam Por Kwan \\ International service-learning (ISL) is \\ conceptualized as an intersection of three \\ educational components: service-learning, study \\ abroad, and international education. Its potential \\ benefits include increases in students' \\ intercultural competence and sense of global \\ citizenship. Arguably, through immersion in a \\ cross-cultural context, students can learn to \\ appreciate diverse values and cultures while \\ enhancing their social responsibility and bringing \\ benefit to a community in need. However, most \\ existing empirical studies of the impact of ISL \\ utilize small samples drawn from a single \\ program, which restricts the generalizability of the \\ findings. This study, using a large sample from \\ multiple courses, aims to bridge the gap by \\ examining the relationship between an ISL \\ experience and university students' global \\ citizenship and intercultural effectiveness. The \\ findings suggest that skills such as intercultural \\ effectiveness and global competencies are more \\ easily enhanced than attitudinal values such as \\ social responsibility and global civic engagement. \\ Implications for practice and future research are \\ discussed.
}

Keywords: global citizenship, intercultural effectiveness, international service-learning

\section{Impacto del aprendizaje-servicio internacional en el desarrollo de la ciudadanía global y la efectividad intercultural de estudiantes universitarios}

\author{
Stephen C. F. Chan, Grace Ngai, \\ Jessie Ho-Yin Yau, y Kam Por Kwan
}

El aprendizaje-servicio internacional (ASI) se define como la intersección de tres componentes educativos: aprendizaje-servicio, estudios en el extranjero y educación internacional. Sus beneficios potenciales incluyen el aumento de la competencia intercultural y el sentido de ciudadanía global de los estudiantes. Podría decirse que, a través de la inmersión en un contexto intercultural, los estudiantes pueden aprender a apreciar los diversos valores y culturas mientras mejoran su responsabilidad social y aportan beneficios a una comunidad necesitada. Sin embargo, la mayoría de los estudios empíricos existentes sobre el impacto delASI utilizan pequeñas muestras extraídas de un único programa, lo que restringe la posibilidad de generalizar los hallazgos. El presente estudio utiliza una gran muestra de diferentes cursos con el objetivo de cerrar la brecha, al examinar la relación entre una experiencia de ASI y la eficacia intercultural y ciudadanía global de los estudiantes universitarios. Los hallazgos sugieren que habilidades como la efectividad intercultural y las competencias globales se pueden mejorarcon mayor facilidad que valores y actitudes como la responsabilidad social y el compromiso cívico global. Asimismo, en el estudio se plantean las implicaciones de estos hallazgos para la práctica y la investigación futura.

Palabras clave: ciudadanía global, efectividad intercultural, aprendizaje-servicio internacional

Editors' Note: English-to-Spanish translation by Beatriz Calvo- Peña

Department of English \& Foreign Languages

Barry University, USA 
International service-learning (ISL), which combines service-learning (SL) with study abroad and international education, is widely regarded as a powerful pedagogy to achieve the goal of nurturing students into responsible global citizens who are able to make meaningful contributions to their profession and the community (Bringle \& Hatcher, 2011; Kiely, 2005; Tonkin, 2004). Owing to the culturally immersive nature and the degree of dissonance and openness to transformational learning that ISL offers (Hartman \& Kiely, 2014), the potential benefits of this pedagogy for students are many. They include improved global competence; increased sense of global citizenship; development of leadership, communication, and teamwork skills; and personal development in the areas of adaptability, maturity, examination of values and beliefs, civic responsibilities and civic engagement (Bringle, 2017; Brown, 2007; Chamberlin, 2016; Nickols et al., 2013).

Whereas ISL has been increasingly explored and integrated into the curriculum of tertiary education (Nickols et al., 2013; Stearns, 2009), research on the impact of ISL on students and the community is still relatively scant (Crabtree, 2008). A review of the literature shows that most of the research to date is in the form of descriptive case studies of particular courses and programmes with small samples (Jones \& Steinberg, 2011; Kiely \& Hartman, 2011). As Rubin and Matthews (2013) have pointed out, many aspects of ISL have yet to be explored. Bringle et al. (2011) argued that there was a strong need for additional research on the outcomes and impact of ISL on students and communities, particularly studies that are more quantitative in nature, and on the impact across multiple academic subjects or programs.

This study aims to bridge the research gap by evaluating, using a combination of quantitative and qualitative methods, the impacts of a number of ISL subjects and initiatives on student learning outcomes at a university in Hong Kong - particularly their global competence and citizenship development. The study is guided by the following research question: "To what extent did students' participation in an ISL experience enhance their global citizenship and intercultural effectiveness development?".

\section{Literature Review}

\section{International Service-Learning}

International service-learning (ISL) is an experiential learning pedagogy that promotes student learning and development through a combination of service-learning, study abroad, and international education (Bringle \& Hatcher, 2011; Crabtree, 2008). In addition to the service experience, it also provides students with opportunities to integrate with a different community and culture (Tonkin \& Quiroga, 2004). ISL, being a particular form of SL, involves a purposive integration of meaningful service with rigorous academic study and reflections on the service experience. It emphasizes reciprocity (Jacoby, 2015) as well as equal benefits to the students and the community (Furco, 1996). It differs, however, from conventional SL in two important ways. First, it involves the conducting of service activities beyond national boundaries or in regions with a different culture. Second, it usually has goals that are more international or global in nature including, for example, increased intercultural awareness and sensitivity, enhanced intercultural competencies, improved understanding of international or global issues, and/or global citizenship development.

A growing body of research has shown that ISL enhances a multitude of student learning outcomes in higher education including ethical and moral development, professional development, increased cultural awareness, cross-cultural and international skill development, broadened worldview, increased awareness and understanding of vulnerable or marginalised groups or social inequalities, and increased awareness of the importance of socially responsible approaches to community engagement (Brett, 2015). Moreover, ISL has been found to help develop in students a deeper understanding of the reasons behind the underprivileged experiences of the service recipient group (King, 2014). It also enables students to make personal connections with those communities and to develop a greater sense of being immersed in the communities (Maher, 2003). In a qualitative study of 16 university participants enrolled in a 10-day STEM-based ISL course, Daniel and Mishra (2017) found that ISL had a positive impact on students' ABC (affective, behavior, and content) development as well as their civic awareness. 


\section{Global Citizenship}

One of the most prominent goals of ISL is to enhance the global citizenship development of the participants (Bringle \& Hatcher, 2011). However, there is no single, generally accepted definition of global citizenship within the literature (Larsen, 2014). McGrew (2000) and Shultz (2007) distinguished three paradigms of global citizenship that underpin the most prevalent definitions:

- the neoliberalist view that stresses the necessary skills and knowledge needed for an individual to successfully participate in the world;

- the radicalist view that emphasises the recognition of global inequalities and a commitment to challenge, and ultimately eliminate, unjustified problems across countries; and

- the transformationalist view that highlights collaborative efforts to solve global issues and make the world a better place for all.

Notwithstanding the differences among definitions, educators generally perceive global citizenship as a multidimensional concept covering awareness, responsibility, and engagement on a global scale (Schattle, 2009). On the basis of an extensive review of the literature, Morais and Ogden (2011) proposed a multifaceted conceptual model that provides a useful framework for understanding and measuring global citizenship (Van Cleave, 2013). Their model encompasses three core dimensions, as follows:

- Social Responsibility - the perceived level of interdependence and social concern towards others, society, and the environment;

- Global Competence - having an open mind while actively seeking to understand others' cultural norms and expectations and leveraging this knowledge to interact, communicate, and work effectively outside one's environment; and

- Global Civic Engagement - the demonstration of actions and/or disposition toward recognizing local, state, national, and global community issues, and responding through actions such as volunteerism, political activism, and community participation. (Morais \& Ogden, 2011, pp. 447448)

While it is argued that ISL is a powerful pedagogy to enhance students' global citizenship development (Brown, 2011; Plater et al., 2009), relatively few studies have been conducted on the impact of ISL on students' development as global citizens (Larsen, 2014; Tonkin, 2011), and it has been argued that more study is needed in this aspect (Bringle \& Hatcher, 2011).

\section{Intercultural Competence}

Intercultural competence is a critical component of global citizenship, and it requires an understanding of the globalized world (Deardorff \& Edwards, 2013). The difference is that, whereas global citizenship stresses civic actions and human rights, intercultural competence focuses more on cultural differences. While there has been much debate and discussion on the concept of intercultural competence (Deardorff, 2009), in the broadest sense, intercultural competence can be defined as the set of abilities an individual needs to possess to behave appropriately and effectively in situations interacting with culturally diverse others (Fantini \& Tirmizi, 2006; Sinicrope et al., 2007). It comprises three main dimensions: relevant cultural knowledge, receptive attitudes, and integrated skills to apply the knowledge and attitude for intercultural interaction (Javidan \& Teagarden, 2015).

ISL is potentially beneficial to students' intercultural competence development because of its opportunities for intercultural interaction and its immersive nature, neither of which can be easily replicated in a classroom setting (Deardorff \& Edwards, 2013). Through ISL, students can improve their intercultural awareness and intercultural communication skills with service recipients who may have a cultural background that is different from theirs (De Leon, 2014). However, there have been scant studies on the relationship between ISL and intercultural competence (Tonkin, 2011), and more studies are therefore required to investigate the effectiveness of ISL in enhancing students' intercultural competence. 


\section{Methodology}

\section{Research Setting}

The study involved eight service-learning subjects and 13 ISL projects from a broad spectrum of disciplines offered by a large public university in Hong Kong in the 2016/17 academic year. All subjects carried three credits and had a 40-hour service component that was closely linked to the academic focus of the subject. Students were encouraged to reflect on their ISL experience and link it with the academic content of the course through debriefings, sharing sessions, reflective journals, or reports. Student performance and learning was assessed according to a letter-grade system. The nature of the service projects varied; they included English language teaching, public health promotion, vision screening, and installation of smallscale solar energy systems. Those projects also covered a diverse range of service beneficiaries, including primary school children, secondary school children, households in urban deprived areas, and rural village dwellers. The service sites included Cambodia, Myanmar, Vietnam, and Rwanda as well as Mainland China and Taiwan. (Even though the racial demographic of Mainland China and Taiwan are very similar to Hong Kong's, historical and linguistic factors create an environment that is culturally very distinct.)

The proposal for the study was reviewed and approved by the university's Ethics Committee (which oversees all research involving human or animal subjects). The investigators were given permission and access to the target participants, totaling 417 students.

\section{Research Design}

The study adopted the mixed methods triangulation design (Creswell et al., 2003), with the aim of obtaining different but complementary data to best understand the research problem (Morse, 1991). The rationale for this approach is that through collecting quantitative and qualitative data on the same research problem, it allows triangulation of results from the two methods to strengthen the robustness of the study and give the researchers greater certainty in inferences and conclusions drawn from the findings (Ponce \& PaganMaldonado, 2015).

\section{Quantitative}

The quantitative part of the study adopted a pretest-posttest design. Global citizenship was measured using a short version of the Global Citizenship Scale (GCS), which was originally developed by Morais and Ogden (2011) and validated with 348 undergraduate students in the United States. The short scale version (GCS-SS) was developed and validated with university students in Hong Kong; results showed that the short version was reasonably reliable and valid (Lo et al., 2014; Lo et al., 2019). It comprises a total of 15 items: four on social responsibility, five on global competence, and six on global civic engagement. Students were asked to indicate, on a 5-point scale ( $1=$ strongly disagree; $3=$ neutral; $5=$ strongly agree), their extent of agreement with each of the declarative statements describing various aspects of global citizenship.

The Intercultural Effectiveness Scale (IES) (Portalla \& Chen, 2010) was used to measure students' level of intercultural competence prior to and after completing the ISL project. The IES measures the respondents' competencies in interacting effectively with people from a different culture. It was validated with 246 students in the United States. It comprises 20 items in total. Students were asked to indicate, on a 5-point scale ( 1 = strongly disagree; $3=$ neutral; $5=$ strongly agree), the extent to which they agreed with each of the statements regarding their attitude and behaviors when interacting with people from different cultures.

The pre-survey was administered in class by the course instructor or staff members from the university's Office of Service-Learning at the beginning of the semester. The post-survey was administered by the course instructor on or after the last day of the ISL project. In all administrations, the purpose of the survey was clearly explained to the students, with the assurance that their response would not affect their assessment grades. Students were given 15 to 20 minutes to complete the questionnaire and were asked to 
return it immediately afterwards. Email invitations were sent at least twice to follow up with nonrespondents to urge them to complete and return the questionnaire via email. Data were analyzed using SPSS version 24 software. Paired t-tests and Cohen's effect size (Cohen's $d$ ) were conducted to detect if there were any statistically significant changes in students' pretest and posttest scores as measured by GCSSS and IES.

\section{Qualitative}

Qualitative data were used to corroborate the quantitative findings. The qualitative part of the study took the form of semi-structured interviews. Questions in the interview protocol were designed to address the impact of the ISL project, particularly in the aspects of global citizenship and intercultural effectiveness development. Students were asked to explain how, if at all, they had changed and what they had learned in terms of global citizenship and intercultural effectiveness as a result of participating in ISL.

Students were categorized according to their response to the relevant item on the post-experience survey (whether they felt that the experience of studying the SL subject had transformed them) into two groups. The first group (Group A) consisted of students giving a rating of five or below while the second group (Group B) consisted of students giving a rating of six or above. For each of the 13 projects, one or two students were nominated from each group by the respective subject teachers based on class size. Students were invited by email to participate in an interview and were asked to reply within seven days. They were promised a HK\$200 ( US\$26) coupon upon completing the interview. A total of 44 students finally accepted the invitation and attended the interview.

The interviews were conducted by the Service-Learning and Leadership Office staff in the students' native language or a language that they felt comfortable with (Cantonese, Mandarin, or English) according to the pre-set protocol. Prior to the interview, participants were briefed on the purpose of the study. Voluntary participation and confidentiality of data were emphasized and written informed consent was obtained from all participants. Each interview lasted about 1 to 1.5 hours; they were audio-recorded with the permission of the interviewees to facilitate subsequent transcription and data analysis.

The interviews were first transcribed verbatim in the language in which they were conducted. Data were then content analyzed independently by two members of the project team to identify whether and how ISL impacted students' global citizenship and intercultural competence development, using a grounded theory approach (Charmaz, 2006; Creswell, 2013). As part of the data analysis, a coding scheme was developed; the codes were linked to the categories and themes that were allowed to emerge from the data without preconceptions (Noble \& Smith, 2014). Direct quotes from the participants were selected to support and illustrate the categories and themes identified. Differences between opinions and views of the two members were discussed until agreement was reached.

\section{Results}

\section{Quantitative Findings}

A total of $142(38.1 \%)$ of the respondents were male and $231(61.9 \%)$ were female. The average age was 20.5 years $(\mathrm{SD}=1.452)$. Further, $211(50.6 \%)$ did their service project in Mainland China or Taiwan, and $206(49.4 \%)$ participated in an ISL project.

\section{Global Citizenship Development}

Table 1 shows statistically significant increases in students' overall score on the Global Citizenship Scale (pretest $=3.44$; posttest $=3.54 ; \mathrm{t}=-4.24 ; \mathrm{p}<.001$; effect size $($ Cohen's $d)=0.26$ ) and their score on the Global Competence subscale (pretest $=3.62$; posttest $=3.87 ; \mathrm{t}=-7.70 ; p<.001$; effect size (Cohen's $d)=0.49$ ). The changes in the Social Responsibility and Global Civic Engagement subscale scores, however, were not statistically significant at .05 level. 
6 International Journal of Research on Service-Learning and Community Engagement

Table 1

Changes in Students' Mean Scores on Global Citizenship

\begin{tabular}{lccccc}
\hline Measures & $\begin{array}{c}\text { Pretest } \\
\text { Mean } \\
{[\text { [SD] }}\end{array}$ & $\begin{array}{c}\text { Posttest } \\
\text { Mean } \\
{[\text { [SD] }}\end{array}$ & t-value & $\boldsymbol{p}$ & $\begin{array}{c}\text { Effect size } \\
\text { (Cohen's } \boldsymbol{d} \text { ) }\end{array}$ \\
\hline Global Citizenship Scale & & & & & \\
Social responsibility & 3.43 & 3.42 & 0.392 & .695 & -0.01 \\
Global competence & {$[0.75]$} & {$[0.86]$} & & & \\
& 3.62 & 3.87 & -7.70 & $<.001^{* *}$ & 0.49 \\
Global civic engagement & {$[0.48]$} & {$[0.54]$} & & & \\
& 3.29 & 3.34 & -1.30 & .195 & 0.08 \\
Overall & {$[0.59]$} & {$[0.69]$} & & & 0.26 \\
& 3.44 & 3.54 & -4.24 & $<.001^{* *}$ & \\
\hline
\end{tabular}

$* * p<.01$

\section{Intercultural Competence}

Table 2 shows that there is a statistically significant increase in students' score on the Intercultural Effectiveness Scale after their ISL experience (pretest $=68.40$; posttest $=70.98 ; \mathrm{t}=-6.14 ; p<.001$ ), with an effect size (Cohen's $d$ ) of 0.34 .

Table 2

Changes in Students' Mean Scores on Intercultural Effectiveness

\begin{tabular}{lccccc}
\hline \multicolumn{1}{c}{ Measures } & $\begin{array}{c}\text { Pretest } \\
\text { Mean } \\
\text { [SD] }\end{array}$ & $\begin{array}{c}\text { Posttest } \\
\text { Mean } \\
\text { [SD] }\end{array}$ & t-value & $\boldsymbol{p}$ & $\begin{array}{c}\text { Effect size } \\
\text { (Cohen's } \boldsymbol{d} \text { ) }\end{array}$ \\
\hline $\begin{array}{l}\text { Intercultural Effectiveness } \\
\text { Scale }\end{array}$ & 68.40 & 70.98 & -6.14 & $<.001^{* *}$ & 0.34 \\
\hline
\end{tabular}

$* * p<.01$

\section{Qualitative Findings}

The qualitative findings serve as evidence that corroborates the quantitative results. Students reported an increase in intercultural communications skills, increased intercultural awareness and understanding. Students found communicating with people with different culture and linguistic backgrounds not as difficult as they had imagined. Even if they had originally been hesitant and concerned about English proficiencytheir own or the community's - they discovered that communication could be done without complete or totally grammatically correct sentences. Students noticed that using simple and major keywords or body language and movement could be sufficient for daily communication, which is important in an intercultural 
setting. For example, one student said: "Because of the pronunciation or the choice of words ... it was difficult because they might not understand what we were talking about. ... But when you used some keywords, they would understand." Another student stated:

When a lot of body movements were involved or when pictures were provided, we could communicate even without words, that was a huge gain. ... Indeed, it worked; we could connect with them. Even when the local peer was absent, the local villagers could understand what I said.

In addition, from the qualitative interviews, we found that students had an increased sense of global competence. They kept their minds open while they were trying to understand and appreciate the local citizens' cultural norms and expectations. One student noted how the ISL experience inspired her to reconsider and challenge the stereotypes:

In the beginning, I knew nothing about the country; all the information I found about it online was about the genocide. From the beginning, I thought the country was poor and sad. I felt upset. ... The local citizens seemed to have a low standard of education, and it seemed that we would need to expend a huge amount of effort to explain our stuff and collaborate with them.... But when I arrived in the country, it was different from my expectations. ... Through working with the local university students and communicating with the local citizens, I was impressed by how fast they learned. ... They were actually smart. ... We actually could exchange many ideas with them rather than just "we go there and teach them."

Another student mentioned how he appreciated the local culture through the sensitivity training workshop:

I remembered that there was a half-day session during which we learned about the [country's] culture, their etiquette, their words and numbers, their games and some dancing movements. ... I particularly liked that session ... because in Hong Kong, we majorly rely on social media to keep connecting with people, but in [country], some low-cost activities would already be able to link people together.

In addition, the ISL experience helped students to shift out of the "tourist gaze" (Urry, 1990) and motivated them to understand more about the country, including the social issues, education, hygiene, and even global issues. By visiting slums and historical sites, students began to see the world as interconnected, in the sense that historical events are similar in nature or cause. One of the students was stimulated to think about how the history taught him lessons that he could use to analyze current social issues:

Mass killing was not unique to [country]; other countries also experienced it. ... In fact, what happens in the world is interconnected to a certain extent.... We shared similar histories. [Country] had poverty problems; Hong Kong also has poverty problems. It is just that the poverty level or situation is different. ... In [country], the poverty problem may affect their education. ... I would think what we or the government could do to alleviate the problems.

Although students demonstrated certain gains in global competence through the interviews, when asked about their gains in global citizenship, most of them said they do not know what it was. Some students mentioned no gain in global citizenship at all. For instance: "Not much change in terms of global citizenship. I could say I'm more open-minded after the trip, but not really about global citizenship, I guess."

\section{Discussion}

Consistent with previous studies, this study shows that students did learn quite a lot from the ISL experience, at least from their own perspective. Students gained increased cultural awareness (Curtin, et al., 2013; Green et al., 2011; Plumb et al., 2013) as well as skills in cross-cultural and international development (Green et al., 2011; Marsolek et al., 2012; Walsh, 2003).

There is strong evidence to support the notion that ISL has a significant positive impact on students' intercultural effectiveness and global competence development, as indicated by the increases in students' 
scores on the Intercultural Effectiveness Scale and Global Competence subscale of the Global Citizenship Scale after the experience. The results suggest that, through ISL, students were immersed in a different culture for an extended period, which improved their ability to interact with people from different cultural backgrounds (Deardorff \& Edwards, 2013; Maher, 2003; Sinicrope et al., 2007). This finding is also supported by the qualitative data from the interviews, in which students reflected on how they developed a deeper understanding of the history and culture of the host community through interacting with the service recipients and the locals. The students became more open-minded and understanding towards others' cultural norms and expectations.

There is, however, little evidence from the study to support the seemingly intuitive belief that ISL will invariably facilitate students' global citizenship development. Although a significant increase was observed in students' overall score on the Global Citizenship Scale, the increase was attributed mainly to the large increase in the Global Competence subscale score mentioned above. Interviews with students revealed that many students did not know what global citizenship entailed, and very few of them reported any improvements in this aspect. These results contradict previous research, which found that ISL shifts students towards becoming global citizens (Larsen, 2014). The discrepancy could be explained by the difficulty in changing students' attitudes and beliefs in a short period of time (Lee et al., 2007).

Furthermore, although it is deemed an important goal of ISL, many teachers participating in the present study expressed that they had not explicitly included global citizenship in the intended learning outcomes or syllabus, and they made little intentional effort to design and incorporate effective interventions to foster its development through the ISL experience. Another possibility is that some items on the measurement of the global civic engagement dimension might not be applicable to the Hong Kong context. It is rather uncommon or unlikely for Hong Kong students to engage in some of the civic engagement actions specified in items such as "over the next 6 months, I will contact a newspaper or radio to express my concerns about global environmental, social, or political problems"; "I will express my views about international politics on a website, blog, or chat room"; and "I will contact or visit someone in government to seek public action on global issues and concerns." On the other hand, Hong Kong students do evidence other forms of civic activities, such as street marches, protest performances, display of banners in private or public spaces, and business boycotts. Although GCS-SS has been validated in the Hong Kong context, further modifications might be needed if students' civic engagement actions are to be measured more accurately.

\section{Limitations and Implications}

This study has several limitations. First, as this study did not involve a control group, the possibility that the positive changes and students' growth were due to other factors such as maturation effect cannot be ruled out completely. Second, as the learning gains were self-reported, there may be over- or underreporting due to recall bias. Third, the study was based on students' feedback only. Fourth, the study was conducted in one university in Hong Kong with a particular form of ISL. The findings are not generalizable to other universities in other countries with different forms of ISL. Notwithstanding, the study supports the commonly held belief that ISL can have strong positive impacts on student learning outcomes, particularly intercultural effectiveness and global competence development.

Based on the above limitations, four recommendations for future ISL research are as follows: First, future research could involve a control group and comparing the results with an intervention group to examine the impact of ISL. Second, objective, additional data such as subject grades could be analyzed as one of the outcome variables to offset the limitation of self-reported data. Third, feedback from instructors could be collected as data to evaluate students' growth as a result of the ISL experience, which would provide another perspective. Fourth, replicating the research in other universities with ISL could be revealing and possibly enhance the generalizability of the findings. Fifth, longitudinal studies could be conducted to measure the long-term impact of an ISL experience on students' attitudes and behaviors.

Moreover, for ISL teachers and future programs, more attention should be paid to developing students' global citizenship through ISL. Additional guidance and support should be given to teachers, particularly those who had little experience of global citizenship education prior to engaging in ISL. It is important for 
teachers to make this goal explicit in the intended learning outcomes of the program or subject and for them to be intentional in designing effective interventions to achieve it. Teaching methods that include issue trees, consequence maps, global citizenship self-assessment tools, and relevant reflection prompts could be helpful in global citizenship education and development (Yau et al., 2018).

Furthermore, given that the concepts and the manifestations of social responsibility, global citizenship, and global civic engagement are very dependent upon one's cultural and political context, it may be necessary to develop more appropriate scales for measuring student learning gains in these dimensions. As mentioned above, certain items in the Global Civic Engagement subscales do not seem very relevant to the Hong Kong context. Scales that are not explicitly linked to particular forms of political involvement would perhaps be more widely applicable as these can vary significantly across cultures, countries, and political systems.

\section{References}

Brett, D. (2015). International service learning: Analytical review of published research literature. Frontiers: The Interdisciplinary Journal of Study Abroad, 25, 107-131.

Bringle, R. G., \& Hatcher, J. A. (2011). International service learning. In R. G. Bringle, J. A. Hatcher, \& S. G. Jones (Eds.), International service learning: Conceptual frameworks and research (pp. 328). Stylus.

Bringle, R. G., Hatcher, J. A., \& Williams, M. J. (2011). Quantitative approaches to research on international service learning: Design, measurement, and theory. In R. G. Bringle, J. A. Hatcher, \& S. G. Jones (Eds.), International service learning: Conceptual frameworks and research (pp. 275-290). Stylus.

Bringle, R. G. (2017). Hybrid high-impact pedagogies: Integrating service-learning with three other highimpact pedagogies. Michigan Journal of Community Service Learning, 24(1), 49-63.

Brown, N. (2007). Embedding engagement in higher education: Preparing global citizenship through international service-learning. Campus Compact 20th Anniversary Visioning Summit. Retrieved August 28, 2010, from http://www.compact.org/resources/future-of- campusengagement/embedding-engagement-in-higher-education-preparing- global- citizens-throughinternational-service learning/4235/

Brown, N. (2011). A 360-degree view of international service learning. In R. G. Bringle, J. A. Hatcher, \& S. G. Jones (Eds.), International service learning: Conceptual frameworks and research (pp. 328). Stylus.

Charmaz, K. (2006). Constructing grounded theory. SAGE.

Crabtree, R. D. (2008). Theoretical foundations for international service-learning. Michigan Journal of Community Service Learning, 15(1), 18-36.

Creswell, J. W., Plano Clark, V. L., Gutmann, M., \& Hanson, W. (2003). Advanced mixed methods research designs. In A. Tashakkori \& C. Teddlie (Eds.), Handbook of mixed methods in social and behavioral research (pp. 209-240). SAGE.

Creswell, J. W. (2013). Qualitative inquiry and research design (3rd ed.). SAGE.

Chamberlin, M. (2016). Exploring the short-term impact of international service learning on adolescent participants in Cambodia [Unpublished Master's thesis, Royal Roads University]. https://www.yogawithbhakti.com/uploads/1/2/6/4/12646463/m._chamberlin_ma final thesis.pdf 
Curtin, A. J., Martins, D. C., Schwartz-Barcott, D., DiMaria, L., \& Oganda, B. M. S. (2013). Development and evaluation of an international service learning program for nursing students. Public Health Nursing, 30(6), 548-556. https://doi.org/10.1111/phn.12040

Daniel, K. L., \& Mishra, C. (2017). Student outcomes from participating in an international STEM service-learning course. SAGE Open, 7(1), 1-11. https://doi.org/10.1177\%2F2158244017697155

De Leon, N. (2014). Developing intercultural competence by participating in intensive intercultural service-learning. Michigan Journal of Community Service Learning, 21(1), 17-30.

Deardorff, D. K. (2009). Implementing intercultural competence assessment. In D. K. Deardorff(Ed.), The SAGE handbook of intercultural competence (pp. 477-491). SAGE.

Deardorff, D. K., \& Edwards, K. (2013). Framing and assessing intercultural competence in service learning. In P. H. Clayton, R. G. Bringle, \& J. A. Hatcher (Eds.), Research on service learning: Conceptual frameworks and assessment (pp. 157-183). Stylus.

Fantini, A., \& Tirmizi, A. (2006). Exploring and assessing intercultural competence. World Learning Publications, Paper 1. https://digitalcollections.sit.edu/worldlearning_publications/1/

Furco, A. (1996). Service-learning: A balanced approach to experiential education. Expanding boundaries: Service and learning. Corporation for National Service, 2-6.

Green, S. S., Comer, L., Elliott, L., \& Neubrander, J. (2011). Exploring the value of an international service-learning experience in Honduras. Nursing Education Perspectives, 32(5), 302-307.

Hartman, E., \& Kiely, R. (2014). Pushing boundaries: Introduction to the global service-learning special section. Michigan Journal of Community Service Learning, 21(1), 55-63.

Jacoby, B. (2015). Service-learning essentials: Questions, answers, and lessons learned. Jossey-Bass.

Javidan, M., \& Teagarden, M. B. (2015). Conceptualizing and measuring global mindset. In W. H. Mobley, M. Li, \& Y. Wang (Eds.), Advances in Global Leadership (Vol. 6, pp. 13-39). Emerald Group. https://doi.org/10.1108/S1535-1203(2011)0000006005

Jones, S. G., \& Steinberg, K. S. (2011). An analysis of international service-learning programs. In

R. G. Bringle, J. A. Hatcher, \& S. G. Jones (Eds.), International service learning: Conceptual frameworks and research (pp. 89-112). Stylus.

Kiely, R. (2005). A transformative learning model for service-learning: A longitudinal case study.

Michigan Journal of Community Service Learning, 12(1), 5-22.

Kiely, R., \& Hartman, E. (2011). Qualitative research methodology and international service learning. In R. G. Bringle, J. A. Hatcher, \& S. G. Jones (Eds.), International service learning: Conceptual frameworks and research (pp. 291-317). Stylus.

King, J. T. (2004). Service-learning as a site for critical pedagogy: A case of collaboration, caring, and defamiliarization across borders. Journal of Experiential Education, 26(3), 121-137. https://doi.org/10.1177\%2F105382590402600304

Larsen, M. A. (2014). Critical global citizenship and international service learning. Journal of Global Citizenship \& Equity Education, 4(1). https://journals.sfu.ca/jgcee/index.php/jgcee/article/view/112

Lee, S-Y., Olszewski-Kubilius, P., Donahue, R., \& Weimholt, K. (2007). The effects of a service-learning program on the development of civic attitudes and behaviors among academically talented adolescents. Journal for the Education of the Gifted, 31(2), 165-197. https://doi.org/10.4219\%2Fjeg-2007-674 
Lo, K. W. K., Kwan, K. P., Ngai, G., \& Chan, S. C. F. (2014, November 20-21). An initial exploration of the cross-cultural validity of the Global Citizenship Scale in the Hong Kong setting [Paper presentation]. The 1st International Conference on Service-Learning, Hong Kong.

Lo, K. W. K., Kwan, K. P., Ngai, G., \& Chan, S. C. F. (2019, January 10-12). Cross-cultural validation of the global citizenship scale for measuring impacts of international service-learning in Hong Kong setting [Paper presentation]. The 3rd International Conference on Service-Learning, Hong Kong.

Maher, M. J. (2003). Individual beliefs and cultural immersion in service-learning: examination of a reflection process. Journal of Experiential Education, 26(2), 88-96. https://doi.org/10.1177\%2F105382590302600206

Marsolek, M. D., Alcantara, J. T., Quintero, L. F., Jackels, C. F., Cummings, P. K., Wayne, M., Vallejos, C., \& Jackels, S. C. (2012). Wastewater treatment for a coffee processing mill in Nicaragua: A service-learning design project. International Journal for Service Learning in Engineering, 7(1), 69-92. https://doi.org/10.24908/ijsle.v7i1.4242

McGrew, A. (2000). Sustainable globalization? The global politics of development and exclusion in the new world order. In T. Allen \& A. Thomas (Eds.), Poverty and development into the 21 st century (pp. 345-364). Oxford University Press.

Morais, D. B., \& Ogden, A. C. (2011). Initial development and validation of the Global Citizenship Scale. Journal of Studies in International Education, 15(5), 445-466.

Morse, J. M. (1991). Approaches to qualitative-quantitative methodological triangulation. Nursing Research, 40(2), 120-123.

Nickols, Y. N., Rothenberg, N. J., Moshi, L., \& Tetloff, M. (2013). International service-learning: Students' personal challenges and intercultural competence. Journal of Higher Education Outreach and Engagement, 17(4), 97-124.

Noble, H., \& Smith, J. (2014). Qualitative data analysis: A practical example. Evidence-Based Nursing, 17(1), 1-3. http://dx.doi.org/10.1136/eb-2013-101603

Plater, W. M., Jones, S. G., Bringle, R. G., \& Clayton, P. H. (2009). Educating globally competent citizens through international service learning. In R. Lewin (Eds.), The handbook of practice and research in study aboard: Higher education and the quest for global citizenship (pp. 485-505). Routledge.

Plumb, E., Roe, K., Plumb, J., Sepe, P., Soin, K., Ramirez, A., Baganizi, E., Simmons, R., \& Khubchandani, J. (2013). The use of international service learning initiatives for global health education: Case studies from Rwanda and Mexico. Health Promotion Practice, 14(3), 334-342. https://doi.org/10.1177\%2F1524839913476516

Ponce, O. A., \& Maldonado, N. P. (2015). Mixed methods research in education: Capturing the complexity of the profession. International Journal of Educational Excellence, 1(1), 111-135.

Portalla, T., \& Chen, G. M. (2010). The development and validation of the Intercultural Effectiveness Scale. Intercultural Communication Studies, 19(3), 21-37.

Rubin, D. L., \& Matthews, P. H. (2013). Learning outcomes assessment: Extrapolating from study abroad to international service-learning. Journal of Higher Education Outreach and Engagement, 17(2), 67-85.

Schattle, H. (2009). Global citizenship in theory and practice. In R. Lewin (Ed.), The handbook of practice and research in study abroad: Higher education and the quest for global citizenship. Routledge. 
Shultz, L. (2007). Educating for global citizenship: Conflicting agendas and understandings. The Alberta Journal of Educational Research, 53(3), 248-258.

Sinicrope, C., Norris, J. M., \& Watanabe, Y. (2007). Understanding and assessing intercultural competence: A summary of theory, research, and practice. Retrieved December 30, 2017, from http://www.hawaii.edu/sls/wp-content/uploads/2014/09/Norris.pdf

Stearns, P. (2009). Educating global citizens in colleges and universities: Challenges and opportunities. Routledge.

Tonkin, H. (2004). Service-learning across cultures: Promise and achievement. International Partnership for Service-Learning and Leadership.

Tonkin, H. (2011). A research agenda for international service learning. In R. G. Bringle, J. A. Hatcher, \& S. G. Jones (Eds.), International service learning: Conceptual frameworks and research (pp. 191-224). Stylus publishing.

Tonkin, H., \& Quiroga, D. (2004). A qualitative approach to the assessment of international servicelearning. Frontiers: The Interdisciplinary Journal of Study Abroad, 10, 131-149.

Urry, J. (1990). The tourist gaze: Leisure and travel in contemporary societies. SAGE Publications.

Van Cleave, T. J. (2013). Short-term international service-learning: Faculty perceptions of and pedagogical strategies for the design and implementation of successful learning experiences [Unpublished doctoral dissertation, Portland State University]. PDXScholar. https://doi.org/10.15760/etd.1055

Walsh, L. V. (2003). International service learning in midwifery and nursing education. Journal of Midwifery \& Women's Health, 48(6), 449-454. https://doi.org/10.1016/S1526-9523(03)00310-6

Yau, J. H. Y., Tong, S. K. P., \& Kwan, K. P. (2018). Educating global citizenship through international service-learning: A toolkit for teachers. Office of Service- Learning, Hong Kong Polytechnic University.

\footnotetext{
About the Authors

Stephen C. F. Chan is a consultant in the Service-Learning and Leadership Office at The Hong Kong Polytechnic University (Hong Kong).

Grace Ngai is the head of the Service-Learning and Leadership Office and an associate professor of computing at The Hong Kong Polytechnic University (Hong Kong).

Jessie Ho-Yin Yau was a project officer in the Service-Learning and Leadership Office at The Hong Kong Polytechnic University (Hong Kong).

Kam Por Kwan is a professorial project fellow in the Service-Learning and Leadership Office at The Hong Kong Polytechnic University (Hong Kong).

Correspondence concerning this article should be addressed to Stephen C. F. Chan at stephen.c.chan@polyu.edu.hk.
} 